\title{
Fractured Ties: Power Competition and Politics Influencing Security Strategies of Kenya and Somalia in the Horn of Africa Region
}

\author{
Abel Bennett Holla ${ }^{1}$ \\ ${ }^{1}$ Chuka University \\ P. 0. Box 109-60400, Chuka, Kenya
}

DOI: $10.22178 /$ pos. $71-6$

JEL Classification: K40

Received 15.05.2021

Accepted 28.06.2021

Published online 30.06.2021

Corresponding Author:

abelholla@gmail.com

(C) 2021 The Author. This article

is licensed under a Creative Commons Attribution 4.0 License @) (1)

\begin{abstract}
Kenya and Somalia share a common pre- and post-colonial history, and both countries have a substantial ethnic Somali population. They also share a resource-rich marine boundary, which has been the centre of controversy as each country claims it. Additionally, both Kenya and Somalia are critical players in the Horn of Africa region. Their security relations will to a significant extent, determine the peace and stability of the region. Although the consideration of power competition could primarily shape Somalia's security strategy in the Horn of Africa region, the role of domestic politics and economic factors in Somalia's strategic thinking cannot be discounted. Kenya has primarily adopted a pragmatic approach to managing her relations with Somalia over the past decade. With Kenya and Somalia sharing a long porous border, which is frequented by al-Shabaab and other insurgent groups, it is expected that skirmishes will erupt as forces on either side tackle security threats. Other pertinent issues affecting the Kenya-Somalia relations include increased piracy, unlicensed, illegal and unreported fishing along the Gulf of Aden alongside toxic waste dumping in the area. To ensure that these activities are controlled and curtailed, there is a need for solid cooperation, notwithstanding the long-simmering differences between the two nations. Based on a wide range of sources, this article examines salient issues contributing to simmering tension between Kenya and Somalia. It also provides a critical evaluation of Kenya's perceptions of Somalia and their implications.
\end{abstract}

Keywords: Shifta; militia, marginalization.

\section{INTRODUCTION}

On January 25, 2021, heavy fighting broke out in the Somali town of Bulo Hawo between Somali forces and those from the federal territory of Jubbaland, which borders Kenya. Later on, the same day, Somalia's information ministry accused what it said were Kenya-funded rebels of crossing into the border town and attacking Somali forces. Somalia's accusation that Kenya supported the Jubbaland leader came after Somalia cut diplomatic ties with Kenya in December 2020, citing a need "to safeguard Somalia's unity, sovereignty, and stability" [1]. However, a fact-finding mission created by the Intergovernmental Authority on Development (IGAD) found no evidence supporting violations by Kenya [2].

Kenya and Somalia share a common pre- and post-colonial history, and both countries have a substantial ethnic Somali population. They also share a resource-rich marine boundary, which has been the centre of controversy as each country claims it. Another common and highly divisive issue is the menace of terrorism. The terrorist group Harakat al-Shabaab al-Mujahideen, more commonly known as Al-Shabaab, is considered the main antagonist. Attempts to bring the threat of terror attack by this group under control have occasionally led to misunderstandings between the two countries.

In the months leading to Kenya's independence from the British Colonial rule in 1963, there was unwillingness by the Kenyan government to cede the north-eastern region to Somalia, which was, and remains, predominantly Somali-inhabited [3]. This resulted in control measures by Kenya, which were later known as the Shifta War. The Shifta Wars pitted Kenyan forces on the one side 
and rebel forces of predominantly indigenous Somalis of Kenyan origin who wished to join the newly independent Somali. The Kenyan Somalis united behind an amorphous unit called the Northern Province Progressive People's Party (NPPPP). The Northern Province Progressive People's Party grew into a ragtag militia and then into a complete revolution, which among other things, called for the union of the Kenyan Somalis with those of the Somalia republic [3]. The Northern Province Progressive People's Party was funded and armed by the Somali government, which received support and assistance from the USSR. Coming at the peak of the Cold War, it became a war that Kenya had a particular interest in because Kenya was a capitalistic country amid many other countries sympathetic to communist ideology.

Having come from a long period of oppression by the British, the Kenyan government quickly adopted similar strategies employed by their former colonial master in dealing with the military wing of the NPPPP. This wing, now known as Northern Frontier District Liberation Army (NFDLA), had merged into battalions of around 1,000 men and spread around the three districts of Wajir, Garissa and Mandera [3]. With modern weapons sourced from Somalia, they had enough capacity to launch effective warfare, including mine warfare. Kenya's first reaction was to brand the NFDLA as 'Shifta' or bandits, effectively removing the revolutionary tag that they claimed. The north-eastern area was then made a controlled zone, and further to this, the president was permitted to have direct oversight authority over the region. This act was entrenched in the constitution to validate and legitimize it [4].

In the subsequent years, the Kenyan government's lack of adequate support led to marginalization by communities living in the North Eastern Province (as it was later renamed in the post-independence provincial division). The feeling of disenfranchisement affected communities in the greater North Eastern Province and the indigenous Somali people who inhabited these areas. With few infrastructural developments, hospitals, schools, and other social and physical amenities, the area soon strengthened Somalia's familial and cultural ties. Despite the ending of the Shifta Wars, the frosty relationship between Somalia and Kenya was never addressed by any of the concerned parties [5]. Moreover, the situation in North Eastern Province was aggravated by the prolonged instability in neighbouring Somalia under Mohammed Siad Barre's then-president. After his ouster as president, the development and growth of terrorist group Al-Shabaab exacerbated instability in the region. The kinship, proximity, and long porous border between Somalia and Kenya, which by design cut across the primarily Somali tribe, made a situation that was terrible worsening.

Therefore, it is plausible that with their highly similar backgrounds, the Kenyan Somalis and their relatives across the border in Somalia have a shared dream of unity under one government. However, with claims of an elaborate plan to have all Somalis under one unitary state, it is reasonable to posit that there would be problems between these two states.

\section{RESULTS AND DISCUSSION}

Kenya and Somalia share a resource-rich sea boundary. However, the extent of the territorial borders has been a subject of dispute. This has mainly been intense with the normalization of the political situation in Somalia after the relative subduing of the al-Shabaab terrorists. Such stability has led to Somalia seeking to exploit natural resources, which it believes are within its territorial boundaries. The dispute between the two countries is based on the direction of their common maritime border. Kenya contends that the border should take a 45-degree angle at the shoreline and run parallel to the latitudinal line. At the same time, Somalia thinks that the border should run along their south-eastern border with Kenya [6]. This contention led Somalia to seek the International Court of Justice (ICJ) to resolve the matter.

Somalia resisted an out of court dispute solution because it believed that its best chances lie with the matter being heard and determined by the ICJ. On the other hand, Kenya sought to influence Somalia to handle the matter out of court. The opinion held by Kenya being that this is an issue that is more existential and more about the potential oil and gas resources undersea. Moreover, Kenya's approach to the issue was also motivated by the need to access the Indian Ocean. Emotive as the matter can be, both sides of the divide have stood their ground, with government and parliaments on either side digging into their perceived right. In August 2019, Kenyan lawmakers called on the government to do what was necessary to protect Kenya's sovereignty and territorial integrity. Not long after these calls by the parliamentarians, the 
Somali parliament also conveyed the same message to its government.

Moreover, due to the disputed marine boundary between the two countries, there have been debates about who owns the resources within the disputed area. Despite being referred to the International Court of Justice, Somalia has been accused of acting in bad faith to exploit the resources. In 2019, Kenya accused Somalia of auctioning oil drilling rights along the (East) African coast despite the area being under contention. As discussed earlier, the matter has been referred to the International Court of Justice (ICJ) and is awaiting determination. The prominent bone of contention is where the boundary lies- whether it is parallel to the latitude as per Kenya's assertion or in line with Somalia's claim that it should follow the south-eastern Kenya-Somali border in its extension into the sea hold muster [7].

It should be noted that it was not the recommended approach at the initial stage of the disagreement. At first, in 2009, the countries had sought the indulgence of the United Nations commission in charge of mediating border disputes where it was decided that it would be better to continue with talks, which would bring an amicable and mutually benefiting outcome. However, it would seem that Somalia grew impatient, and in 2014 they sued Kenya at the ICJ. Somalia's approach is one of the solutions available to feuding countries, which have failed at bilateral or regional negotiations. Somali claimed that despite numerous discussions on how the dispute could be solved, there lacked any progress on the way forward.

Although both countries are out for an 'all-ornothing' outcome, it is felt that this would exacerbate matters between the two states. Concession between the two parties is advised with the sharing of the contested area and mining raw materials. In West Africa, this has been realized, with positive results being achieved between Nigeria and the archipelagic state of Sao Tome and Principe.

Somalia's stance is that agitating and demanding the recognition of the maritime border is increasingly being taken by states in Africa interested in setting their maritime borders. This could be attributed to the increasing number of discoveries of oil and mineral deposits beneath the sea. In protecting any incursions, a state can take advantage of any riches within its maritime borders. With Somalia having come out of lawlessness and improving its governance, it seeks to assert its control. It is expected that it will continue in its push for its borders to be recognized internationally. Consequently, the maritime border case at the International Court of Justice provides it with an excellent opportunity to assert its legitimacy as a country.

It has been opined that finding and developing lasting solutions, a formula for sharing the resources, should be adopted. This would shift the scenario from a win-lose to a win-win situation to the advantage of both countries. Examples have been proffered of countries which have benefited from such arrangements. Prominent among them is the Nigeria-Sao Tome agreement, which saw the archipelagic state and the continental nation share the proceeds from the common area along the Atlantic.

Although both Kenya and Somalia consider the territorial dispute a divisive issue, the potential damages that both countries may suffer by severing their ties would be significant. Somalia benefits immensely from the Kenyan military reinforcement within the African Union Mission in Somalia (AMISOM), which came in to contain the threat posed by the terrorist group al-Shabaab. Kenya also provides asylum to many Somalis who fled Somalia after the fall of the Siad Barre government in 1991. It is also worth noting that there is increased rhetoric of 'invasion' from the al-Shabaab because of Kenya's presence in Somalia. In the event the decision of the ICJ favours Kenya, it might attract renewed and increased terrorist activities as a form of retaliation from the al-Shabaab. The effect would be that the Horn of Africa region would experience increased instability.

The fate of the more than 300,000 refugees from Somalia who are mainly in the Daadab refugee camp and many others interspersed throughout Kenya would be another thorny issue in the event Somalia severs ties with Kenya. With Nairobi being a central and focal point for humanitarian aid coordination for conflict-affected Somalia, it is clear that the worsening of relations between the two states would bring about unprecedented difficulties for the refugees. This has further been aggravated by Kenya's announcement in 2021 that it intends to close the Daadab refugee camp- a clear manifestation of the effects of the embittered relations between the two countries [8].

The third issue would be the increase in piracy, unlicensed, illegal and unreported fishing along the Gulf of Aden alongside toxic waste dumping in 
the area. To ensure that these activities are controlled and curtailed, there is a need for solid cooperation, notwithstanding the long-simmering differences between the two nations. In the peak of high seas robbery and piracy, countries along the region lost between US $\$ 300$ and $\$ 400$ million per year in the shipping sector and around US\$15 million from tourism.

The third issue is the recognition of Somaliland as a state by Kenya. Somaliland is a territory in the northern region of Somalia whose self-declaration of independence from Somalia has never been recognized by the international community. Due to this status of non-recognition, it retains contacts with very few countries in the world, primarily strategic, concessional and infrastructure agreements [9]. However, there has been a thawing of relations with many countries recognizing Somaliland and willing to open consulates and trade in recent years. In December 2020, the Kenyan government pledged to open a consulate in Hargeisa, and Somaliland responded by opening one in Nairobi. Kenya has also projected the commencement of direct flights between Hargeisa and Nairobi by March 2021. This move may have irked the leadership of Somalia, which has never recognized Somaliland's declaration of independence in 1991. Somalia contends that Somaliland is not a distinct nor independent state but a region of the greater Somalia, a globally held position.

Despite the reservations by Somalia as concerns the assertion of Somaliland to be an independent state, specific parameters have led the countries that have recognized Somaliland, including Kenya, to regard it as such. These considerations include: incompatibility with the 'parent' state; assertion to self-determination does not result in changes in international boundaries; assertion to self-determination is amiable to inter-state peace, and seclusion of Somaliland would amount to an abuse of the political principle of self-determination [10].

Somaliland asserts that it is incompatible with the southern side of the greater Somali. This incompatibility is occasioned by the different colonial heritages of Somali and Somaliland, thus occasioning a unique identity to each side of the northsouth divide. Therefore, when self-determination is grounded on the differences in historical experiences, there lacks a reason to deny the party claiming it. This provides Somaliland, and by extension any nation recognizing it, the requisite grounds for self-determination and the right for such action to be recognized.

Secondly, some pundits argue that since the envisaged self-determination is not likely to bring about a change in international boundaries or threaten interstate peace, it should not be denied. This is further supported by Somaliland's assertion that the boundaries demarcated by the British in 1960 shall be respected in its claim for selfdetermination. Moreover, being a cardinal principle in international law, it goes without saying that states that have decided to recognize Somaliland, at least with a consular office, are cognisant of the adherence to this tenet and are satisfied is no absurdity in their recognition of Somaliland [11].

Thirdly, self-determination is supported when it has a promise for providing more conducive interstate peace. It cannot be gainsaid that Somaliland is more stable than Somalia, a fact that enhances the support being received by Kenya in its quest for self-determination. Additionally, Somaliland's respect for colonial borders fosters resolving the longstanding disputes between Ethiopia, Djibouti and Kenya.

Moreover, Somalia's abuse of the principle of selfdetermination in causing atrocities upon Somaliland places even more impetus on the claim for self-determination. This is seen in two issues that underpin their demand; the rejection of a unified constitution in a referendum and the UN practice of conducting a plebiscite before secession (as was seen in South Sudan) [12]. From the above reasons, Kenya's support and recognition of Somaliland may be seen as justifiable.

With Kenya and Somalia sharing a long porous border, which is frequented by al-Shabaab and other insurgent groups, it is expected that skirmishes will erupt as forces on either side tackle security threats. In the recent past, there have been incursions by military forces from Somalia into Mandera County in Kenya while pursuing Jubbaland's security minister, Abdirashid Janan. Kenya voiced its serious objection to this move. Jubbaland is a semi-autonomous region of Somalia that comprises three regions; Geddo, Middle Juba and Lower Juba, with Middle Juba being in control of the Al-Shabaab in most of its area [13].

Somalia claimed that Abdirashid Janan was being harboured in Kenya's town of Mandera after escaping from a prison in Mogadishu. He had been held there for crimes including escaping from 
lawful government custody, international human rights violations, and the massacre of civilians in the Geddo region during a spate of sectarian fighting. However, these claims by Somalia were discounted by Janan, who claimed that his arrest was influenced by Jubbaland elections and the desire of the forces from the Federal Government of Somalia to exert further control over the Jubbaland region. It was alleged that Somalia had desperately tried to influence election outcomes to have a government in office sympathetic to its cause. However, these efforts did not succeed as the incumbent won another term in office. Consequently, the pre-existing rifts were bound to manifest [14].

In seeking to protect Janan, forces from Jubbaland were stationed near Mandera. In March 2020, the forces launched attacks on Beled Hawo, a Somalia-controlled area. This attack led to the deaths of dozens of innocent civilians. In retaliation and seeking to secure Beled Hawo, Somalia sent its forces and the ensuing battle spilt over into Kenya, causing damage to Kenyan owned property and leading to residents fleeing for fear of being harmed.

Somalia further accuses Kenya of interference with its internal matters since Kenya supports the leadership of Jubbaland and its leader Sheikh Madobe. Nairobi favours Jubbaland and its leadership as it not only provides a buffer between AlShabaab and Kenya but has also been instrumental in denying the terrorist group incursions into Kenyan territory in the past [15].

The spillover of violence and intra-state skirmishes into Kenya from Somalia does not portend well for the fragile yet necessary cooperation between the two countries. On the one hand, it seems like Somalia is deliberately instigating these skirmishes to irk Kenya. But, on the other hand, Kenya's support of the Jubbaland government is seen as meddling in the internal affairs of Somalia, which Somalia construes as an overt disrespect of its state's sovereignty.

The attacks on Kenyans by the Al-Shabaab has been another cause of the tense relationship between Kenya and Somalia. After the fall of
Mohammed Siad Barre's government in 1991, Somalia sunk into near-anarchy, with various groups seeking to fill the governance vacuum. Among the groups, one arose and morphed into a terrorist entity, naming itself the Al-Shabaab. Since then, Kenya has been suffering sporadic and deadly attacks by Somalia - based terrorist organizations. The most notable attack being the Garissa University College massacre in April 2005, where 147 people, mainly students, were killed by the terrorists. Other attacks claimed by the AlShabbab include the Westgate shopping mall in 2015 , attacks on vehicles in various parts of Kenya's north-eastern region, Gikomba market bombings, and Mpeketoni and Lamu attacks of 2014. Following these attacks, Kenya has accused Somalia of allowing the fighters to set up base in Somalia and continue their Kenya attacks.

It is worth noting that since 1991, Somalia has not had a central government; it is only in 2011 that the current government gained authority. Before this, clan warlords who individually controlled small parts of the country led the country. This led to the gradual growth of Islamic extremist groups that morphed into the Al-Shabaab. With the terrorist group comparing itself to Al Qaeda in its initial stages and later with Daesh, also known as ISIS, the region is known little relative peace has become a hotspot for terrorist activities [16]. The terror group's incursion into Kenya and its involvement in various sporadic and coordinated attacks culminated in the 2011 launch of Operation Linda Nchi, which saw Kenya's troops enter Somalia to support the government of Somalia to take a foothold and bring normalcy to the country.

\section{CONCLUSIONS}

Despite the support received by Somalia, it has been argued that the government of Somalia is not doing its utmost to contain the terrorist menace. Moreover, since neighbouring countries have contributed their workforce, skills and artilleries to aid the cause, attacks have been experienced in these countries. Consequently, some countries have expressed growing concerns that the government of Somalia is not severe in its fight against terrorists.

\section{REFERENCES}

1. Aljazeera. (2021, January 25). Somali troops, Jubbaland regional forces clash ahead of elections. Retrieved from https://www.aljazeera.com/news/2021/1/25/somali-troops-jubbalandregional-forces-battle-near-kenya-border 
2. Mutambo, A. (2021, January 27). Somalia threatens to leave IGAD over Kenya dispute. Retrieved from https://www.theeastafrican.co.ke/tea/news/east-africa/somalia-kenya-dispute-3271226

3. Mburu, N. (2005). Bandits on the Border: The Last Frontier in the Search for Somali Unity. Trenton: Red Sea Press.

4. Lochery, E. (2012). Rendering difference visible: The Kenyan state and its Somali citizens. African Affairs, 111(445), 615-639. doi: 10.1093/afraf/ads059

5. Ringquist, J. (2011). Bandit Or Patriot: The Kenyan Shifta War 1963-1968. Baltic Security \& Defence Review, 13(1), 100-121.

6. Castagno, A. (1964). The Somali-Kenyan Controversy: Implications for the Future. The Journal of Modern African Studies, 2(2), 165-188.

7. Rothwell, D. (2016). The International Law of the Sea. London: Bloomsbury Publishing.

8. Nzwili, F. (2013, November 14). Long at home in Kenya, Somali refugees feel pressure to leave. Retrieved from https://www.csmonitor.com/World/Africa/2013/1114/Long-at-home-inKenya-Somali-refugees-feel-pressure-to-leave

9. Social Research and Development Institute. (2013). Somaliland Statehood, Recognition and the Ongoing Dialogue with Somalia. Retrieved from

https://ke.boell.org/sites/default/files/somaliland_statehood_recognition_and_the_ongoing_dial ogue_with_somalia.pdf

10. Roethke, P. (2011). The Right to Secede under International Law: The Case of Somaliland. Journal of International Service, 2(3), 35-48.

11. Coggins, B. (2006). Secession, Recognition \& the Internal Politics of Statehood (Doctoral Dissertation), The Ohio State University. Columbus.

12. Bryden, M. (2004). Somalia and Somaliland. African Security Review, 13(2), 23-33. doi: $10.1080 / 10246029.2004 .9627282$

13. Lewis, I. M., \& Lewis, I. M. (2002). A modern history of the Somali: Nation and state in the Horn of Africa. Oxford: James Currey.

14. Chau, D. (2010). The fourth point: An examination of the influence of Kenyan Somalis in Somalia. Journal of Contemporary African Studies, 28(3), 297-312. doi: 10.1080/02589001.2010.497347

15. Howell, J. (1968). An Analysis of Kenyan Foreign Policy. The Journal of Modern African Studies, 6(1), 29-48.

16. Hansen, Stig Jarle. (2013). Al-Shabaab in Somalia: The History and Ideology of a Militant Islamist Group. (Somali Society, History and Politics Series). London: Hurst Publishers. 